\title{
Impact of Some New Generation Insecticides on Beneficial Rhizospheric Microorganisms in Rice Maize Cropping System
}

\author{
Abhijit Ghosal $^{1 *}$, Anushweta Hati ${ }^{2}$, Sujit Mal ${ }^{3}$, Anupam Mukherjee ${ }^{1}$ and \\ Ananya Mukherjee ${ }^{2}$ \\ ${ }^{1}$ Sasya Shyamala Krishi Vigyan Kendra, RKMVERI, Narendrapur, \\ West Bengal-700103, India \\ ${ }^{2}$ IRDM Faculty Centre, RKMVERI, Narendrapur, West Bengal-700103, India \\ ${ }^{3}$ Department of Agriculture Chemistry and Soil Science, Bankura Campus, BCKV, \\ West Bengal, India \\ *Corresponding author
}

\section{A B S T R A C T}

\section{Keywords}

Chlopyrifos, Imidacloprid, Insecticides, Soil microorganisms

\section{Article Info}

Accepted: 07 April 2018 Available Online: 10 May 2018
In modern agriculture there is a pivotal role of pesticides in pest management though, the side effect pesticides on soil biological system is non avoidable. Experimental result shows that imidacloprid recorded $21.42 \%$ increased azotobacter population while chlorpyrifos recorded $31.04 \%$ less azotobacter in comparison with untreated check. All the treatments showed negative impact on the rhizobium population and rate of growth inhibition was $30.81 \%$ to $55.18 \%$; whereas the inhibition rate was ranged $22.08 \%$ to $54.37 \%$ in case of total bacteria population. Proliferation of fungal propagules gets hindered due to application of insecticides $(14.02 \%$ to $43.22 \%$ ). Propagation of fungal propagules was significantly decreased in soil treated with chlorpyrifos. Application of phorate, rynaxypyr and carbofuran also had an inhibitory effect to the growth and multiplication of fungal population. Vivid reduction of phosphate solubilising bacteria (PSB) population was noticed during 28 days after application of insecticides; rynaxypyr and imidacloprid pronounced $94.68 \%$ inhibition of growth in respect control followed by fipronil (90.68\%). Azotobacter was found less susceptible in comparison to rhizobium, fungi and phosphate solubilizing bacteria.

\section{Introduction}

The backbone of agriculture starts with the "soil", which is considered to be the "skin of the earth" with interfaces between the lithosphere, hydrosphere, atmosphere, and biosphere. The soil is an awfully dynamic, complex and highly heterogeneous system that allows the development of an extremely large number of ecological habitats, the home of an array of living organisms that perform important functions for the ecosystems (Gardi and Jeffery, 2009). The array of living organisms in soil is mostly dominated by organisms such as bacteria, fungi, nematodes, arthropods, enchytraeids and earthworms (Jeffery et al., 2010). No one would deny that there is a formidable biological component to 
soils (Dindal, 1990). It is also undeniable that the fauna, microbes, and roots in healthy soils play a number of interactive functional roles like central functions in organic matter decomposition, the nutrient cycle, enhancement of soil structure and the control of organisms including crop pests (Moore and Walter, 1988). The different soil microbes the important component of soil food webs regulates the atmospheric composition, water balance and reduction of soil pollution (Lavelle et al., 2006; Jeffery et al., 2010). They usually act as chemical engineers, biological regulators and ecosystem engineers (Turbe et al., 2010). It is unfortunate, therefore, that as scientists we are still rather naive in our understanding of soil ecology while the farmers still rather naive in understanding the role of this faunas to maintain the health of the soil. Modern technologies demands optimum management practices, fertilizer-responsive varieties, fertilizers and pesticides but have markedly modified traditional crop growing environments. Insecticides have saved millions of human and animal lives since the date of their synthesis and use. They have played an important role that brought revolution in the field of agriculture and human health on control of insect pests of crops and vector-borne diseases (Liu and Xiong, 2001). More than 80,000 chemical substances are now commercially available in agriculture and industry. About 4.6 million tons of pesticides are applied into the environment and insecticides accounted for the largest portion of total use in the world to increase the productivity of food and fibre as well as to prevent the incidence of vectorborne diseases. However the side effects of pesticides on the soil microflora were studied by several workers (Munees and Mohammad, 2011; Dave et al., 2005; Ahmad and Ahmad, 2006). Pesticides may affect the microbial population by controlling the survival and reproduction of the individuals. Amirkhanov et al., (1994) reported field dose of many insecticides have inhibitory effect on soil microbes; whereas, some pesticides stimulate the growth of the microbes or exerted no effects (Ahmed and Ahmad, 2006). There is indirect evidence that crop intensification has decreased species diversity in agricultural fields. Protection of soil quality under intensive land use and fast economic development is a major challenge for sustainable resource use in the developing world (Doran et al., 1996). The basic assessment of soil health and soil quality is necessary to evaluate the degradation status and changing trends following different land use and smallholder management interventions (Lal and Stewart, 1995). So, the present study emphasizes the importance of understanding the effects of insecticide application if any on soil microbes.

\section{Materials and Methods}

Experiment was conducted in the Instructional Farm of Sasya Shyamala Krishi Vigyan Kendra (Farm Science Centre) situated at Arapanch, Sonarpur, West Bengal, which is located at $22.4^{0} \mathrm{~N}$ latitude, $88.2^{0} \mathrm{E}$ longitude during spring summer season of 2014 and 2015 in rice maize cropping system under saline zone of West Bengal. Maize (Var. P740) seeds were sowed in plots measuring $3 \mathrm{~m} \times 3 \mathrm{~m}$ at a spacing of $50 \mathrm{~cm}$ between rows and $25 \mathrm{~cm}$ between plant to plant. Farm Yard Manure @ 5 tons/ha and all the recommended dose of fertilizers $\mathrm{N}$ : P: $\mathrm{K}$ were applied as basal. No fertilizer and plant protection chemicals other than treatment schedule were applied during the crop growth period. Further the insecticides under evaluation viz. rynaxypyr $0.4 \mathrm{G} @ 4 \mathrm{~kg} /$ acre, fipronil $0.3 \mathrm{G}$ @ $5 \mathrm{~kg}$ / acre, cartap hydrochloride $4 \mathrm{Gr} @ 6$ kg/ acre, carbofuran $3 \mathrm{G} @ 7.2 \mathrm{~kg} /$ acre, phorate 10 G @ 5 kg/ acre, imidacloprid 0.5 G @ $23 \mathrm{~kg} /$ acre (sample provided by Bayer Crop Science Pvt. Ltd.) and chlorpyrifos 35 
EC @ $5 \mathrm{ml} / \mathrm{lt}$ (soil drenching) were applied at recommended dose in soil by mixing with fine sand during 45 days after sowing. Soil samples were collected from 6 inch depth before application, 3, 7, 14, 28 and 75 days after insecticide application from each treatments, properly tagged, sealed and carried out from the field to the laboratory for isolation of soil microorganisms. Physicochemical characteristics of the collected soil samples viz. organic carbon (following the method of Walkey and Black, 1934), available phosphorus (determined by using Bray and Klertz method of extraction illustrated by Jackson, 1973 and estimating the extracted phosphorus calorimetrically), available potassium (ascertained by extracting the water soluble and exchangeable forms of Potassium by using neutral, normal ammonium acetate and estimating the extracted potassium with the help of a flame photometer as described by Jackson, 1973) were determined to ascertain the impact of insecticides on soil physicochemical properties and which in turn impart effect on the microbes population, if any. The enumeration of the microbial population was done on agar plates containing appropriate media (Jensen's agar medium for azotobacter, yeast mannitol agar media for rhizoium, pikovskaya's medium for PSB, nutrient agar media for total bacteria and potato dextrose agar medium was used for total fungi population isolation) following serial dilution technique and spread plate method; plates were incubated at $30^{\circ} \mathrm{C}$. The counts were taken after 48 hours of incubation. The results are reported as number of cells per gram of soil. Collected data were analyzed using Duncan's Multiple Range Test (DMRT) to compare the specific difference of mean using SPSS (16) software.

\section{Results and Discussion}

The tabulated result of soil physico-chemical parameters shows that there was no significant change between the initial and final value during the course of experiment. Negligible depletion of soil $\mathrm{pH}, \mathrm{EC}$ and available potassium was noticed; while the level of organic carbon and available phosphorus get increased (Table 1). Degradation of the parent molecule may influence the organic carbon content of the soil. Thus it may be concluded that insecticides used does not impart any significant effect on the test soil parameters. The effect of soil physico-chemical properties being nullified on the microbes present in soil.

\section{Effect of insecticides on nitrogen fixing bacteria}

\section{Azotobacter}

The effect of test insecticides on the azotobacter population in terms of CFU count is presented in table 2. It is clear from the tabulated values that the azotobacter population per gram of soil with $10^{-2}$ dilution in all the treatments prior to application of insecticides was distributed evenly, the range was to the tune of 75-77 nos. During 3 days after application of insecticides in all the treatments the population get reduced, imidacloprid recorded the maximum colony count (61 nos.) and showed higher population (18\%) while chlorpyrifos recorded $46 \%$ less count in respect of control. Rynaxypyr recorded the highest population count (47.33 nos.) among all other treatments after 7 days of insecticides application, while chlorpyrifos showed $48.64 \%$ less count. For the period of 14 days after application phorate recorded maximum population count. During 75 days after application of insecticides all the treated plots showed significant difference in respect of CFU count. Imidacloprid recorded the highest CFU count (81.00 nos.) and chlorpyrifos recorded the lowest (22.33 nos.). The mean population count of azotobacter ranged from 28.77-50.66 nos. Imidacloprid recorded the highest and chlorpyrifos recorded 
the lowest population. In comparison with control imidacloprid recorded $21.42 \%$ increased population while chlorpyrifos recorded $31.04 \%$ less azotobacter in comparison with untreated check.

\section{Rhizobium}

Rhizobium population in per gram of soil with $10^{-3}$ dilution in all the treatments prior to application of insecticides ranged from 112.33-118.00 nos. Drastic reduction of population was noticed on 3 days in cartap hydrochloride treated soil $(91.35 \%)$ followed by chlopyrifos $(90.48 \%)$ in respect of control. Rynaxypyr recorded the highest CFU count (33.00 nos.) followed by fipronil (27 nos.) during 3 days after application. Fipronil showed highest population count (24.00 nos.) among all other treatments while chlorpyrifos recorded the lowest CFU count (5.66 nos.) during 7days after application of insecticides. The observations recorded on 28 days after application of insecticides chlorpyrifos recorded maximum decrease in $\mathrm{CFU}$ count $(60.50 \%)$ followed by carbofuran $(55.29 \%)$ and fipronil $(26.30 \%)$ in respect of untreated check. During 75 days after application of insecticides carbofuran recorded the highest CFU count (64.66 nos.) while chlorpyrifos recorded the lowest (9.33 nos.). Based on mean value after completion of experiment it is unambiguous to say that all the treatments showed negative impact on the rhizobium population. Rate of growth inhibition was $30.81 \%$ to $55.18 \%$ in respect of untreated check (Table 3 ). In respect of mean value of population count it is interesting to note that population of azotobacter was not negatively influenced; while rhizobium was negatively influenced by application test insecticides in comparison with untreated control plot. Thus it may be assumed that rhizobium is more sensitive than that of azotobacter. It is obvious to record that the population of nitrifying bacteria started to recover from 28 days onwards after insecticide application. This clearly pointed out that there was no long term detrimental effect of these insecticides on population of nitrifying bacteria in their recommended dose, though repeated use may pronounce detrimental effect on the soil microbes. This result sustained with the report of earlier workers (Sing et al., 2002; Vig et $a l ., 2008)$ who also indicated that application of insecticides at their recommended field rates did not have any effect on the growth and multiplication of nitrifying bacteria in soil. The growth and proliferation of nitrifying bacteria progressively decreased up to 30 days of sampling followed a decrease after 75 days. This clearly indicated that the insecticides, in general, and their degraded products were utilized by these autotrophs for their growth and metabolism. It was revealed from the results that there was a significant fall in the growth of colonies of nitrifying bacteria in the soil treated with chlorpyrifos, imidacloprid and phorate after 3, 7 and 14 days of sampling. This clearly manifested the harmful effects of degraded products of those insecticides on the population of nitrifying bacteria in soil. This was supported by the findings of Gonzalez et al., (1993).

Table.1 List of physico-chemical parameters of the soil under experimentation

\begin{tabular}{|l|c|c|}
\hline Parameters & Initial value & Final value \\
\hline pH & 5.4 & 5.2 \\
\hline Ec & 0.38 & 0.34 \\
\hline Oxidisable Organic carbon & 0.71 & 0.77 \\
\hline A vailable Phosphorus & $77.86 \mathrm{~kg} / \mathrm{ha}$ & $78.20 \mathrm{~kg} / \mathrm{ha}$ \\
\hline Available potassium & $570 \mathrm{~kg} / \mathrm{ha}$ & $545 \mathrm{~kg} / \mathrm{ha}$ \\
\hline
\end{tabular}


Table.2 Effect of insecticides on Azotobacter (cfu x $10^{2} / \mathrm{g}$ of soil) at different intervals

\begin{tabular}{|c|c|c|c|c|c|c|c|c|}
\hline Treatments & $\begin{array}{c}\text { pre } \\
\text { treatment }\end{array}$ & 3days & 7 days & 14days & 28days & 75days & Mean & $\begin{array}{l}\% \text { reduction/ } \\
\text { increase over } \\
\text { control }\end{array}$ \\
\hline$T_{1}$ & $76.88 \pm 0.88^{a}$ & $51.00 \pm 0.57^{b}$ & $47.33 \pm 1.20^{\mathrm{a}}$ & $25.00 \pm 1.15^{\mathrm{cde}}$ & $12.66 \pm 1.20^{\mathrm{e}}$ & $67.00 \pm 0.5^{\mathrm{bc}}$ & 46.64 & +11.79 \\
\hline$T_{2}$ & $75.00 \pm 1.73^{\mathrm{a}}$ & $31.00 \pm 1.1^{\mathrm{e}}$ & $23.66 \pm 1.76^{\mathrm{c}}$ & $23.00 \pm 1.15^{\mathrm{de}}$ & $21.00 \pm 0.57^{\mathrm{cd}}$ & $65.00 \pm 1.15^{\mathrm{c}}$ & 39.77 & -4.67 \\
\hline $\mathrm{T}_{3}$ & $75.66 \pm 1.45^{a}$ & $45.00 \pm 1.1^{\mathrm{c}}$ & $35.33 \pm 1.20^{b}$ & $30.00 \pm 0.57^{\mathrm{abc}}$ & $26.00 \pm 2.08^{b c}$ & $63.66 \pm 1.33^{c}$ & 45.94 & +10.11 \\
\hline$T_{4}$ & $76.66 \pm 1.85^{a}$ & $36.66 \pm 1.4^{\mathrm{d}}$ & $23.33 \pm 0.88^{c}$ & $23.33 \pm 1.45^{\mathrm{de}}$ & $24 \pm 1.15^{\mathrm{c}}$ & $70.00 \pm 0.57^{b}$ & 42.33 & +1.46 \\
\hline$T_{7}$ & $75.66 \pm 1.20^{a}$ & $27.66 \pm 0.8^{\mathrm{e}}$ & $19.00 \pm 1.15^{\mathrm{d}}$ & $16.00 \pm 1.52^{\mathrm{f}}$ & $12.00 \pm 1.52^{\mathrm{e}}$ & $22.33 \pm 2.60^{\mathrm{g}}$ & 28.77 & -31.04 \\
\hline $\mathrm{T}_{8}$ & $75.66 \pm 0.88^{a}$ & $51.33 \pm 1.4^{\mathrm{b}}$ & $37.00 \pm 2.30^{b}$ & $28.33 \pm 1.85^{b c d}$ & $12.00 \pm 1.52^{\mathrm{e}}$ & $46.00 \pm 1.15^{\mathrm{f}}$ & 41.72 & - \\
\hline
\end{tabular}

$\left(\mathrm{T}_{1}=\right.$ Rynaxypyr, $\mathrm{T}_{2}=$ Fipronil, $\mathrm{T}_{3}=$ Cartap hydrochloride, $\mathrm{T}_{4}=$ Carbofuran, $\mathrm{T}_{5}=$ Phorate, $\mathrm{T}_{6}=$ Imidacloprid, $\mathrm{T}_{7}=$ Chlorpyrifos, $\mathrm{T}_{8}=$ Control$)$

Table.3 Effect of insecticides on rhizobium at different intervals

\begin{tabular}{|c|c|c|c|c|c|c|c|c|}
\hline Treatment & Pre treatment & 3days & 7days & 14days & 28days & 75days & Mean & $\begin{array}{l}\text { \% reduction } \\
\text { increase } \\
\text { over control }\end{array}$ \\
\hline$\overline{T_{2}}$ & $115.00 \pm 1.15^{\mathrm{ab}}$ & $27.00 \pm 1.15^{\mathrm{c}}$ & $24.00 \pm 1.52^{b}$ & $12.66 \pm 1.20^{b c}$ & $9.33 \pm 0.33^{\mathrm{a}}$ & $18.00 \pm 3.46^{\mathrm{ef}}$ & 34.33 & -37.76 \\
\hline $\mathbf{T}_{\mathbf{3}}$ & $118.00 \pm 0.57^{\mathrm{a}}$ & $6.66 \pm 0.88^{f}$ & $9.00 \pm 0.57^{\mathrm{de}}$ & $8.66 \pm 1.20^{c}$ & $12.33 \pm 0.88^{\mathrm{a}}$ & $35.00 \pm 0.57^{b c}$ & 31.60 & -42.71 \\
\hline $\mathrm{T}_{6}$ & $115.33 \pm 2.33^{\mathrm{ab}}$ & $12.33 \pm 0.88^{\mathrm{e}}$ & $10.66 \pm 0.33^{\mathrm{d}}$ & $10.33 \pm 0.88^{c}$ & $13.66 \pm 0.33^{\mathrm{a}}$ & $21.66 \pm 2.08^{\mathrm{def}}$ & 30.66 & -44.41 \\
\hline $\mathbf{T}_{7}$ & $116.67 \pm 0.88^{\mathrm{ab}}$ & $7.33 \pm 1.20^{\mathrm{f}}$ & $5.66 \pm 0.88^{\mathrm{f}}$ & $4.33 \pm 0.88^{\mathrm{d}}$ & $5.00 \pm 1.15^{c}$ & $9.33 \pm 0.57^{\mathrm{g}}$ & 24.72 & -55.18 \\
\hline $\mathrm{T}_{8}$ & $112.33 \pm 0.33^{b}$ & $77.00 \pm 0.57^{\mathrm{a}}$ & $63.66 \pm 3.17^{\mathrm{a}}$ & $40.66 \pm 5.68^{a}$ & $12.66 \pm 1.20^{\mathrm{a}}$ & $24.66 \pm 2.51^{\mathrm{de}}$ & 55.16 & - \\
\hline
\end{tabular}

$\left(\mathrm{T}_{1}=\right.$ Rynaxypyr, $\mathrm{T}_{2}=$ Fipronil, $\mathrm{T}_{3}=$ Cartap hydrochloride, $\mathrm{T}_{4}=$ Carbofuran, $\mathrm{T}_{5}=$ Phorate, $\mathrm{T}_{6}=$ Imidacloprid, $\mathrm{T}_{7}=$ Chlorpyrifos, $\mathrm{T}_{8}=$ Control$)$ 
Table.4 Effect of insecticides on total bacteria in different intervals

\begin{tabular}{|l|c|c|c|c|c|c|c|c|c|}
\hline Treatment & Pretreatment & 3days & 7days & 14days & 28days & $\begin{array}{c}\text { 75days } \\
\text { \%ean reduction/ } \\
\text { increase over } \\
\text { control }\end{array}$ \\
\hline $\mathrm{T}_{1}$ & $85.00 \pm 2.00^{\mathrm{e}}$ & $74 \pm 1.73^{\mathrm{e}}$ & $57.33 \pm 0.66 \mathrm{cde}$ & $22.66 \pm 0.88^{\mathrm{d}}$ & $13.66 \pm 0.88^{\mathrm{cd}}$ & $26.66 \pm 0.88^{\mathrm{c}}$ & 46.55 & -38.91 \\
\hline $\mathrm{T}_{2}$ & $88.33 \pm 2.60 \mathrm{~d}^{\mathrm{e}}$ & $87.66 \pm 0.88^{\mathrm{d}}$ & $73.33 \pm 0.88^{\mathrm{b}}$ & $23.66 \pm 1.76^{\mathrm{d}}$ & $6.00 \pm 0.57^{\mathrm{e}}$ & $33.00 \pm 0.57^{\mathrm{b}}$ & 51.99 & -31.78 \\
\hline $\mathrm{T}_{3}$ & $72.33 \pm 1 .^{20 \mathrm{f}}$ & $67.66 \pm 1.20^{\mathrm{ef}}$ & $53.00 \pm 0.57^{\mathrm{e}}$ & $35.33 \pm 0.88^{\mathrm{bc}}$ & $12.33 \pm 0.88^{\mathrm{cd}}$ & $35.66 \pm 0.33^{\mathrm{b}}$ & 46.05 & -39.57 \\
\hline $\mathrm{T}_{4}$ & $98.33 \pm 1.45^{\mathrm{e}}$ & $95.33 \pm 1.76^{\mathrm{c}}$ & $60.00 \pm 1.73^{\mathrm{c}}$ & $22.33 \pm 0.88^{\mathrm{d}}$ & $6.66 \pm 0.88^{\mathrm{e}}$ & $46.66 \pm 1.45^{\mathrm{a}}$ & 54.88 & -27.98 \\
\hline $\mathrm{T}_{5}$ & $82.33 \pm 1.45^{\mathrm{c}}$ & $87.00 \pm 0.57^{\mathrm{d}}$ & $59.00 \pm 1.15^{\mathrm{cd}}$ & $39.66 \pm 3.52^{\mathrm{b}}$ & $27.00 \pm 2.51^{\mathrm{a}}$ & $36.00 \pm 0.57^{\mathrm{b}}$ & 55.16 & -27.62 \\
\hline $\mathrm{T}_{6}$ & $92.66 \pm 2.02^{\mathrm{cd}}$ & $86.66 \pm 1.45^{\mathrm{d}}$ & $42.00 \pm 0.57^{\mathrm{f}}$ & $34.66 \pm 1.20^{\mathrm{c}}$ & $10.00 \pm 0.57^{\mathrm{de}}$ & $11.33 \pm 0.88^{\mathrm{ef}}$ & 46.21 & -39.36 \\
\hline $\mathrm{T}_{7}$ & $84.66 \pm 3.38^{\mathrm{e}}$ & $45.00 \pm 3.46^{\mathrm{g}}$ & $31.00 \pm 4.16^{\mathrm{g}}$ & $15.33 \pm 1.20^{\mathrm{e}}$ & $14.66 \pm 2.15^{\mathrm{c}}$ & $18.00 \pm 2.08^{\mathrm{d}}$ & 34.77 & -54.37 \\
\hline $\mathrm{T}_{8}$ & $107.33 \pm 2.33^{\mathrm{a}}$ & $146.33 \pm 1.76^{\mathrm{a}}$ & $87.00 \pm 0.57^{\mathrm{a}}$ & $59.33 \pm 0.88^{\mathrm{a}}$ & $21.66 \pm 1.76^{\mathrm{b}}$ & $35.66 \pm 4.48^{\mathrm{b}}$ & 76.21 & - & \\
\hline
\end{tabular}

$\left(\mathrm{T}_{1}=\right.$ Rynaxypyr, $\mathrm{T}_{2}=$ Fipronil, $\mathrm{T}_{3}=$ Cartap hydrochloride, $\mathrm{T}_{4}=$ Carbofuran, $\mathrm{T}_{5}=$ Phorate, $\mathrm{T}_{6}=$ Imidacloprid, $\mathrm{T}_{7}=$ Chlorpyrifos, $\mathrm{T}_{8}=$ Control$)$

Table.5 Effect of insecticides on fungi at different intervals

\begin{tabular}{|l|l|l|l|l|l|l|l|l|}
\hline Treatment & Pretreatment & 3Days & 7Days & 14Days & 28Days & 75Days & $\begin{array}{c}\text { Mean } \\
\text { \%eduction/ } \\
\text { increase over } \\
\text { control }\end{array}$ \\
\hline $\mathrm{T}_{1}$ & $137.00 \pm 2.08^{\mathrm{bcd}}$ & $51.00 \pm 0.57^{\mathrm{a}}$ & $28.00 \pm 1.52^{\mathrm{c}}$ & $22.33 \pm 0.88^{\mathrm{cd}}$ & $1.33 \pm 0.33^{\mathrm{d}}$ & $12.66 \pm 0 .^{3 \mathrm{a}}$ & 42.05 & -15.03 \\
\hline $\mathrm{T}_{2}$ & $134.00 \pm 1.45^{\mathrm{cde}}$ & $38.00 \pm 0.5^{\mathrm{a}}$ & $35.00 \pm 1.00^{\mathrm{b}}$ & $24.66 \pm 0.88^{\mathrm{c}}$ & $7.00 \pm 0.57^{\mathrm{c}}$ & $12.33 \pm 0.8^{\mathrm{a}}$ & 41.83 & -15.47 \\
\hline $\mathrm{T}_{3}$ & $133.00 \pm 1.15^{\mathrm{cde}}$ & $14.33 \pm 0.3^{\mathrm{b}}$ & $13.00 \pm 0.57^{\mathrm{d}}$ & $10.00 \pm 0.57^{\mathrm{ef}}$ & $8.66 \pm 0.33^{\mathrm{bc}}$ & $11.00 \pm 0.5^{\mathrm{ab}}$ & 31.66 & -36.02 \\
\hline $\mathrm{T}_{4}$ & $140.00 \pm 0.88^{\mathrm{ab}}$ & $47.00 \pm 1.1^{\mathrm{a}}$ & $13.33 \pm 0.88^{\mathrm{d}}$ & $10.00 \pm 0.57^{\mathrm{ef}}$ & $4.00 \pm 1.15^{\mathrm{cd}}$ & $14.00 \pm 0.5^{\mathrm{a}}$ & 38.05 & -23.11 \\
\hline $\mathrm{T}_{5}$ & $141.00 \pm 1.76^{\mathrm{ab}}$ & $10.00 \pm 0.5^{\mathrm{b}}$ & $43.33 \pm 1.20^{\mathrm{a}}$ & $36.00 \pm 1.52^{\mathrm{b}}$ & $13.00 \pm 1.15^{\mathrm{b}}$ & $12.00 \pm 0.5^{\mathrm{a}}$ & 42.55 & -14.02 \\
\hline $\mathrm{T}_{6}$ & $132.00 \pm 0.33^{\mathrm{de}}$ & $20.66 \pm 0.8^{\mathrm{b}}$ & $13.66 \pm 2.02^{\mathrm{d}}$ & $6.66 \pm 1.20^{\mathrm{f}}$ & $7.00 \pm 2.30^{\mathrm{c}}$ & $4.00 \pm 0.57^{\mathrm{c}}$ & 30.66 & -38.16 \\
\hline $\mathrm{T}_{7}$ & $144.00 \pm 0.57^{\mathrm{a}}$ & $9.00 \pm 1.15^{\mathrm{b}}$ & $6.66 \pm 1.20^{\mathrm{e}}$ & $3.66 \pm 1.20^{\mathrm{f}}$ & $0.33 \pm 0.33^{\mathrm{d}}$ & $5.00 \pm 1.15^{\mathrm{c}}$ & 28.10 & -43.22 \\
\hline $\mathrm{T}_{8}$ & $138.00 \pm 3.60^{\mathrm{bc}}$ & $36.66 \pm 13.73^{\mathrm{a}}$ & $46.33 \pm 3.71^{\mathrm{a}}$ & $45.66 \pm 8.21^{\mathrm{a}}$ & $20.66 \pm 3.84^{\mathrm{a}}$ & $9.66 \pm 4.09^{\mathrm{ab}}$ & 49.49 & \\
\hline
\end{tabular}

$\left(\mathrm{T}_{1}=\right.$ Rynaxypyr, $\mathrm{T}_{2}=$ Fipronil, $\mathrm{T}_{3}=$ Cartap hydrochloride, $\mathrm{T}_{4}=$ Carbofuran, $\mathrm{T}_{5}=$ Phorate, $\mathrm{T}_{6}=$ Imidacloprid, $\mathrm{T}_{7}=$ Chlorpyrifos, $\mathrm{T}_{8}=$ Control $)$ 
Table.6 Effect of insecticides on phosphate solubilising microorganisms at different intervals

\begin{tabular}{|c|c|c|c|c|c|c|c|c|}
\hline Treatment & Pretreatment & 3days & 7days & 14days & 28days & 75days & Mean & $\begin{array}{l}\% \text { reduction/ } \\
\text { increase over } \\
\text { control }\end{array}$ \\
\hline $\mathbf{T}_{1}$ & $115 \pm 1.15^{\mathrm{ab}}$ & $84.00 \pm 2.08^{\mathrm{a}}$ & $20.00 \pm 1.15^{b}$ & $1.66 \pm 0.33^{\mathrm{e}}$ & $1.33 \pm 0.33^{b}$ & $6.66 \pm 0.33^{\mathrm{cd}}$ & 38.10 & -25.84 \\
\hline$\overline{T_{2}}$ & $112.00 \pm 1.15^{\mathrm{b}}$ & $63.66 \pm 2.0^{b}$ & $13.33 \pm 0.88^{\mathrm{cd}}$ & $1.33 \pm 0.33^{\mathrm{e}}$ & $2.33 \pm 0.33^{b}$ & $15.00 \pm 1.15^{\mathrm{c}}$ & 34.60 & -32.65 \\
\hline$T_{3}$ & $115.33 \pm 1.76^{\mathrm{ab}}$ & $21.00 \pm 1.15^{\mathrm{de}}$ & $18.00 \pm 0.57^{b c}$ & $12.33 \pm 0.88^{b c}$ & $7.00 \pm 1.15^{b}$ & $24.00 \pm 0.57^{b}$ & 32.94 & -35.88 \\
\hline $\mathbf{T}_{4}$ & $118.67 \pm 0.88^{\mathrm{a}}$ & $54.66 \pm 2.02^{c}$ & $22.66 \pm 1.76^{b}$ & $16.66 \pm 0.88^{b}$ & $5.00 \pm 0.57^{b}$ & $5.33 \pm 0.33^{\mathrm{d}}$ & 37.16 & -27.67 \\
\hline $\mathbf{T}_{5}$ & $115.33 \pm 1.76^{\mathrm{ab}}$ & $1.33 \pm 0.33^{\mathrm{f}}$ & $11.00 \pm 0.57^{\mathrm{de}}$ & $10.33 \pm 0.88^{\mathrm{bcd}}$ & $3.00 \pm 0.57^{b}$ & $5.66 \pm 0.88^{\mathrm{d}}$ & 24.38 & -52.54 \\
\hline$T_{6}$ & $114.67 \pm 1.45^{\mathrm{ab}}$ & $2.66 \pm 0.33^{\mathrm{f}}$ & $2 \cdot 33 \pm 0.88^{f}$ & $4.00 \pm 1.15^{\mathrm{de}}$ & $1.33 \pm 0.33^{b}$ & $12.00 \pm 0.57^{\mathrm{cd}}$ & 22.83 & -55.56 \\
\hline $\mathbf{T}_{7}$ & $116.00 \pm 1.52^{\mathrm{ab}}$ & $14.33 \pm 4.37^{\mathrm{e}}$ & $7.00 \pm 0.57^{\mathrm{ef}}$ & $3.33 \pm 0.88^{\mathrm{e}}$ & $5.00 \pm 2.30^{b}$ & $7.00 \pm 2.08^{\mathrm{cd}}$ & 25.44 & -50.48 \\
\hline $\mathrm{T}_{8}$ & $112.33 \pm 1.45^{\mathrm{b}}$ & $66.00 \pm 5.50^{b}$ & $37.66 \pm 4.80^{\mathrm{a}}$ & $32.00 \pm 6.08^{\mathrm{a}}$ & $25.00 \pm 7.21^{\mathrm{a}}$ & $35.33 \pm 7.79^{a}$ & 51.38 & - \\
\hline
\end{tabular}

( $\mathrm{T}_{1}=$ Rynaxypyr, $\mathrm{T}_{2}=$ Fipronil, $\mathrm{T}_{3}=$ Cartap hydrochloride, $\mathrm{T}_{4}=$ Carbofuran, $\mathrm{T}_{5}=$ Phorate, $\mathrm{T}_{6}=$ Imidacloprid, $\mathrm{T}_{7}=$ Chlorpyrifos, $\mathrm{T}_{8}=$ Control) 
Effect of insecticides on total bacteria population in soil

Even distribution of total bacteria population was noted after plating with $10^{-5}$ dilution which was ranged from 72.33-107.33 nos (Table 4). All the insecticides showed negative impact on the population of bacteria present in soil up to 28 days. The data recorded during 7 days after application of insecticides showed that imidacloprid recorded the lowest bacterial count (42.00 nos.). Chlorpyrifos showed maximum decrease of population $(74.16 \%)$ followed by carbofuran $(62.36 \%)$, rynaxypyr $(61.80 \%)$ and fipronil $(60.12 \%)$ at 14 days after application. During 28 days after insecticide application phorate recorded highest bacterial colony count (27.00 nos) followed by chlorpyrifos, rynaxypyr, cartap hydrochloride and imidacloprid. 21.66 nos. of colony was recorded in control. In comparison with control phorate recorded $24.65 \%$ increase of bacterial count while fipronil showed $72.79 \%$ decrease in bacterial count. The data recorded during 75 days after application of insecticides showed an overall increase in CFU count in all the treatments. The mean population of total bacteria over the intervals clearly depicts that the population of total bacteria get reduced. Rate of proliferation inhibition was ranged $22.08 \%$ to $54.37 \%$. Chlorpyrifos recorded the lowest CFU count (34.77nos.) on 75 days after application of the insecticides. The mean CFU count of total bacteria population recorded in control was 76.21 nos. Bacterial population started to increase in soil significantly after 75 days of sampling; which indicated that the toxic effect of insecticides during the early days of sampling was overcome by the total bacteria in the subsequent periods due to utilization of the insecticide as well as its degraded products. Similar observations were also reported earlier regarding the utilization of insecticides by the soil bacteria (Shahi et al.,
2007). The experimental results of the present study also comparable with the results of Ahmed and Ahmed, (2006) who concluded that chlorpyrifos caused significant reduction in number of bacteria. According to Long et al., (2006) application of insecticides reduced soil bacterial populations after the first addition which is completely in line with the findings of present author.

\section{Effect of insecticides on fungal population in soil}

CFU count of fungal population in per gram of soil with $10^{-3}$ dilution in all the treatments ranged from 132.00-144.00 nos. Mixed interaction was noticed during 3 days after application of insecticides. The data recorded during 3 days after application of insecticides showed that rynaxypyr recorded the highest fungal count (51.00 nos.) followed by carbofuran (47.00 nos.), fipronil (38.00 nos.). All the insecticides exerted negative impact on the soil fungus from 7 days and onwards up to 28 days. Chlorpyrifos conferred maximum negative impact on fungal count (75.40\% and $85.62 \%$ respectively on 3 and 7 days after insecticide application). 98.40\% decrease in fungal count was noted in chlorpyrifos treated plot during 28 days after insecticide application. During 75 days the fungal population started regenerating. It is prominent from the mean population count in comparison to control the inhibitory effect was recorded to the tune of 14.02 to $43.22 \%$. In general the proliferation of fungal propagules gets hindered due to application of insecticides. It was revealed that the propagation of fungal propagules was significantly decreased in soil treated with chlorpyrifos thus chlorpyrifos can be considered as most toxic chemical towards fungal population present in soil (Table 5). Application of phorate, rynaxypyr and carbofuran also had an inhibitory effect to the growth and multiplication of fungal 
population. This result is in conformity with the findings of Nimbalkar et al., (1989) and Shukla et al., (1990). The results also pointed out that application of carbofuran influenced the number of fungal colonies after 75 days, as compared to untreated control. Thereafter a fall in the proliferation of fungi was recorded on 28th day followed by a progressive rise in the population of fungi up to the end the experiment. This indicated that the test insecticides on decomposition might have produced ingredients which were harmful to the fungi present in soil and in due course the fungi were adopted to utilize the concerned by-products for their cellular nutrients.

\section{Effect of insecticides on phosphate solubilising bacteria}

The effect of test insecticides on the count of phosphate solubilising bacteria (PSB) has been presented in table 6 , which depicts an even distribution of PSB to the range of 112.00-118.67 nos. Inhibition of multiplication of the PSB was recorded by all the insecticides in all the intervals of observation taken. Vivid reduction of population was noticed during 28 days after application of insecticides; rynaxypyr and imidacloprid pronounced $94.68 \%$ inhibition of growth in respect control followed by fipronil $(90.68 \%)$. It was observed that the population of PSB started to increase after 75 days of insecticide application. The mean CFU count of PSB over the intervals in treated soil ranged from 22.83-38.10 nos., whereas in control it was 51.38 nos. It is prominent from the experimental result that PSB is very much susceptible towards toxicant. The differential influence of different insecticides on phosphate solubilising bacteria was also elaborated by Das and Mukherjee, (2000), and Wani et al., (2005). Das and Mukherjee, (1999) opined that after 75 days slight increase in CFU count was observed indicating the preferential utilization of the degraded products of the insecticides by the phosphate solubilising microorganisms for their cellular metabolism confirm the output of the experiment conducted by the present author.

From the summarized results it may be concluded that insecticides applied exerted detrimental effect on the soil microbes. The population of soil microbes started to proliferate from 28 days onwards except PSB. In case of phosphate solubilising bacteria the rate of inhibition was found much at the same dose of insecticide application, while azotobacter was relatively less susceptible towards insecticides than that of rhizobium and fungi. A pin point conclusion can be drawn from the present result that repeated use of insecticides in soil may hinder the regeneration of the microbial fauna which are the key important factor of maintaining the soil health.

\section{Acknowledgements}

Authors are thankful to Ramakrishna Mission Vivekananda Educational and Research Institute (RKMVERI), Narendrapur, West Bengal, India for giving opportunities to conduct the research.

\section{References}

Ahemad S. and Ahmad M. S. 2006. Effect of insecticides on total number of soil bacteria under laboratory and field condition. Pakistan Entomologist. 28(2): 63-68.

Amirkhanov, D. V. A. G. Nikolenko, F. R. Bagautdinov and Kirillova, S. S. 1994. The effects of field doses of gamma$\mathrm{HCH}$, phoxim, cypermethrin and chlorfluazuron on soil microorganisms. Agrokhimiya. 2: 83-88.

Das, A. C. and Mukherjee, D. 1999. Insecticidal effects on the activity and 
numbers of non-symbiotic $\mathrm{N}_{2}$-fixing bacteria and phosphate solubilizing microorganisms and on some chemical properties of rice soil. Microbiological Research. 153(4): 355-361.

Das, A. C. and Mukherjee, D. 2000. Influence of insecticides on microbial transformation of nitrogen and phosphorus in Typic Ochraqualf soil. Journal of Agricultural and Food Chemistry. 48(8): 3728-3732.

Dave, S., D. S. Steven, M. T. Eva, and Verstraete, W. 2005. Combined effect of fertilizer and herbicide applications on the abundance, community structure and performance of the soil methanotrophic community soil boil. Biochemistry. 37:187-193.

Dindal, D. L. 1990. Soil biology guide. New York: John Wiley \& Sons. Pp. 1349.

Doran, J. W., Sarrantonio, M. and Liebig, M. 1996. Soil health and sustainability In: Advances in Agronomy (Ed.), D. L. Sparks, Vol. 56. Academic Press, San Diego. Pp. 1-54.

Gardi, C. and Jeffery, S. 2009. Soil Biodiversity. Luxembourg, Joint Research Center, European Commission. Pp. 27. Available online, DOI 10.2788/7831.

Gonzalez, R. and Campos, M. 1990. Evaluation of natural enemies of the Phloeotribus scarabaeoides (Bern.) (Col.: Scolitidae) in Granada olive groves. Acta Horticulturae. 286: 355358.

Jackson, M. L. 1973. Soil chemical Analysis. Prentice Hall of Englewood cliffs, New Jersey, USA.

Jeffery, S., C. Gardi, A. Jones, L. Montanarella, L. Marmo, L. Miko, K. Ritz, G. Peres, J. Rombke and Van der Putten, W.H.S. 2010. European Atlas of Soil Biodiversity. European Commission, Publications Office of the European Union, Luxembourg. Pp.128.
Lal, R. and Stewart, B. A. 1995. Soil Management: Experimental Basis for Sustainability and Environmental Quality. Advances in Soil Science. CRC Press, Boca Raton, Florida.

Lavelle, P., T. Decaens, M. Aubert, S. Barot, M. Blouin, F. Bureau, P. Margerie, P. Mora and Rossi, J. P. 2006. Soil invertebrates and ecosystem services. European Journal of Soil Biology. 42: 3-15.

Liu, Y.Y. and Xiong, Y. 2001. Purification and characterization of a dimethoatedegrading enzyme of Aspergillus niger ZHY256 isolated from sewage. Applied Environmental Microbiology. 67: 37463749.

Long, Y. Y., S. Min, F. Hua, W. Xiao and Qiang, C. X. 2006. Responses of soil microorganisms and enzymes to repeated applications of chlorothalonil. Journal of Agricultural and Food Chemistry. 54(26): 10070-10075.

Moore, J. C. and Walter, D. E. 1988. Arthropod regulation of micro- and mesobiota in below-ground food webs. Annual Review of Entomology. 33: 419-439.

Munees, A. and Mohammad, S. K. 2011. Assessment of plant growth promoting activities of rhizobacterium Pseudomonas putia under insecticidestress. Microbiology Journal. 1: 11.

Nimbalkar, S. A., S. N. Pawar, Y. M. Taley and Lanjewar, R. D. 1989. Effect of granular systemic insecticides on soil micro-organisms when applied to control sucking pests on cotton $\mathrm{H}-4$. Magazine, College of Agriculture, Nagpur, 56: 21-24.

Shahi, D. K., P. K. Sangita Singh and Agarwal, B. K. 2007. Effect of endosulfan and nutrient amendments on microbial properties in red lateritic soil of Jharkhand. Journal of Applied Zoological Researches. 18(2): 170-174. 
Shukla, D. S., R. Chaturvedi and Srivastava, S. K. 1990. Effect of various fungicides on microbial population of soil and some soil factors. Journal of Environmental Biology. 11(3): 291-298.

Singh, B. K., A. Walker and Wright, D. J. 2002. Persistence of chlorpyrifos, fenamiphos, chlorothalonil and pendimethalin in soil and their effects on soil microbial characteristics. Bulletin of Environmental Contamination and Toxicology. 69(2): 181-188.

Turbe, A., A. Toni, P. Benito, P. Lavelle, P. Lavelle, N. Ruiz, W.H. Van der Putten, E. Labouze and Mudgal, S. 2010. Soil biodiversity: functions, threats and tools for policy makers. Bio Intelligence Service, IRD, and NIOO, Report for European Commission (DG Environment).
Vig, K., D. K. Singh, H. C. Agarwal, A. K. Dhawan and Dureja, P. 2008. Soil microorganisms in cotton fields sequentially treated with insecticides. Ecotoxicology and Environmental Safety, 69(2): 263-276.

Walkley, A. and I. A. Black. 1934. An examination of Degtjareff method for determining soil organic matter and a proposed modification of the chromic acid titration method. Soil Science. 37: 29-37.

Wani, P. A., A. A. Almas-Zaidi, Khan, and Khan, M. S. (2005). Effect of phorate on phosphate solubilization and indole acetic acid releasing potentials of rhizospheric microorganisms. Annals of Plant Protection Sciences. 13(1): 139144.

\section{How to cite this article:}

Abhijit Ghosal, Anushweta Hati, Sujit Mal, Anupam Mukherjee and Ananya Mukherjee. 2018. Impact of Some New Generation Insecticides on Beneficial Rhizospheric Microorganisms in Rice Maize Cropping System. Int.J.Curr.Microbiol.App.Sci. 7(05): 666-676. doi: https://doi.org/10.20546/ijcmas.2018.705.081 